\title{
Prevalence, Isolation and Identification of Bacterial Canker Pathogens on Sweet Cherry Trees in Tekirdağ
}

\section{Merve BÜLBÜL}

\author{
Mustafa MİRIK
}

\author{
"Namık Kemal Üniversitesi Ziraat Fakültesi Bitki Koruma Bölümü, 59030 Tekirdağ, TURKEY \\ e-mail: mmirik@nku.edu.tr
}

Accepted for publication October 27, 2014

\section{ABSTRACT}

Sweet cherry (Prunus avium L.) is one of the most important fruit trees grown in Tekirdağ. Bacterial canker which reduces yield and quality of sweet cherry fruit and cause death of trees were investigated. For this purpose a survey study was conducted in 2012-2013 and 129 plant tissue samples were collected from symptomatic trees. As a result of survey studies, bacterial canker was determined in all orchards and diseases prevalence rate of bacterial canker was determined as $20-57 \%$. Severity of disease was measured as $20-85 \%$ in Tekirdağ Province depending on orchards. As a result of laboratory studies 41 bacterial isolates of Pseudomonas syringae were obtained. As a result of classical and molecular identification tests, 23 isolates were identified as Pseudomonas syringae pv. morsprunorum and 18 out of 41 isolates were identified as a Pseudomonas syringae pv. syringae.

Keywords: Cerasus avium, LOPAT, GATTa, Pseudomonas syringae pv. syringae, Pseudomonas syringae pv. morsprunorum

\section{ÖZET}

Kiraz (Prunus avium L.) Tekirdağ' da yetiştirilen önemli bir meyve türüdür. Kirazda verim ve kaliteyi düşüren, ağaçları kurutan kiraz dal kanseri hastalığı bu çalışma ile araştırılmıştır. Tekirdağ ili kiraz bahçelerinde 2012-2013 yıllarında gerçekleştirilen sörvey araştırmaları sonucu 129 ayrı hasta bitki örneği toplanmıştır. Tekirdağ ilinde sörveylenen bahçelerin tümünde hastalık yaygınlığı \%20-57 oranında, enfekteli ağaçların \%20-85 oranında hastalık şiddetine sahip olduğu tespit edilmiştir. Laboratuarda yapılan çalışmalar sonucu bu örneklerden 41 farklı Pseudomonas syringae izolatı elde edilmiștir. Yapılan klasik ve moleküler tanı testleri sonucunda 23 izolatın Pseudomonas syringae pv. morsprunorum, 18 izolatın ise Pseudomonas syringae pv. syringae olduğu tanılanmıştır.

Anahtar kelimeler: Cerasus avium, LOPAT, GATTa, Pseudomonas syringae pv. syringae, Pseudomonas syringae pv. morsprunorum,

\section{GíRiş}

Meyveler insan beslenmesinde eskiden beri önemli yer tutmaktadır. Çünkü meyvelerin sağladıkları kalori, içerdikleri tuz, asitler ve vitaminler insan beslenmesinde büyük öneme sahiptirler (Gerçekçioğlu ve ark. 2006).

Türkiye birçok meyvenin anavatanı ve meyvecilik kültürünün beşiğidir. Bugün meyvecilik tarımında önem kazanmış olan elma, armut, ayva, erik, üzüm, incir gibi birçok meyve türü ülkemiz topraklarında ortaya çıkmıştır. Hazar Denizi ile Karadeniz arasındaki bölge kirazın anavatanı olarak bilinmektedir. Avrupa ve diğer kıtalara kirazın yayılması tohumların kuşlar, diğer hayvanlar ve göçmenler tarafından taşınmalarıyla olmuştur. Türkiye'de her bölgede kiraz yetiştiriciliği yapılmakta olup üretilen kirazın hemen hemen hepsi taze halde tüketilmektedir (Burak 2003).

Dünyada kiraz üretimi coğrafik olarak dünyanın farklı bölgelerine yayılmış durumdadır. Dünyada 2012 yılı kiraz üretimi 2.256.519 ton olup bu üretimin yaklaşık \%21.30 'unu Türkiye, \%17.04'ünü Amerika Birleşik Devletleri (ABD), \%8.86 'sını İran üretmektedir. Türkiye' nin 2012 yllı kiraz üretimi 480.748 ton olup birinci sirada yer almaktadır. ABD 2012 yılında 384.646 tonluk üretimi ile ikinci sırada olup bunu sırasıyla İran ve İtalya izlemektedir.

Ülkemizde kiraz üretimi son yıllarda gerek ağaç sayısı gerekse üretim olarak sürekli artış göstermektedir. 2013 yılında meyve veren ağaç sayısı 17.922.000 meyve vermeyen ağaç sayısı ise 7.236.000 adet ağaçtan 494.325 ton kiraz üretimi gerçekleşmiş̧ir (TÜIKK, 2013). İl bazında kiraz üretiminde İzmir, Manisa ve Konya ilk sıralarda yer almaktadır. Tekirdağ ilindeki kiraz üretimi ise yıllık 2.441 ton olarak gerçekleşmektedir (TÜíK 2013).

Ülkemizdeki kiraz üretimini tehdit eden pek çok biyotik ve abiyotik sorunlar vardır. Fitopatolojik problemler arasında yaprak delen hastalığına neden olan Stigmina carpophila, monilya (mumya) hastalığına neden olan Monilinia laxa, dal yanıklı̆ğ hastalığına neden olan Nectria galligena, bakteriyel hastalıklardan ise bakteriyel 
kansere neden olan Pseudomonas syringae pv. syringae ve Pseudomonas syringae pv. morsprunorum gibi önemli hastalık etmenleri hem ürün kayıplarına hem de ağaç ölümlerine neden olmaktadır.

Pseudomonas syringae'nin neden olduğu dal kanseri hastalığı dünyada meyve üretimi yapılan her yerde yaygın olarak görülmektedir. Hastalık mücadelesinin zor olmasından dolayı kirazda her yıl önemli verim kayıplarına neden olmaktadır. Fidan üretim alanlarında meydana gelen sistemik enfeksiyonlar sonucunda da fidan ölümleri sonucunda önemli ekonomik kayıplar meydana gelmektedir. Hastalıktan dolayı her yıl Almanya'da ağaçların \%30’u ölürken, benzer kayıplar İtalya ve diğer Avrupa ülkelerinde de görülmektedir (Kennelly ve ark. 2007).

Hastalığa neden olan bakteriyel etmenler Pseudomonas syringae pv. syringae ve Pseudomonas syringae pv. morsprunorum düz ya da eğik çubuk şeklinde, bir veya iki kamçıya sahip gram negatif hücre yapısına sahiptir. Eni 0.5-1 $\mu \mathrm{m}$, boyu 1.5-4.0 $\mu \mathrm{m}$ arasında değişmektedir. DNA' nın \%58-71 mol' ü G+C içermektedir (Schaad ve ark. 2001). Pseudomonas syringae'nin ilk orijinal izolat1 1902 yılında Van Hall tarafindan hastalıklı bir leylak (Syringae vulgaris) bitkisinden izole edilmiştir. Pseudomonas syringae kompleks bir patojen olup Gardan ve ark. (1999) önce 56 farklı pathovarlarının bulunduğunu ve DNA:DNA hibridizasyonu sonucunda izolatların 6 genomospeciese ayrıldığını belirlemişlerdir. Kaluzna ve ark. (2012) ise etmenin yaklaşık 64 pathovarı olduğunu bildirmiştir. Bunlar DNA:DNA hibridizasyonuna göre genom yapısı açısından 3 farklı genomospeciese ayrılmıştır. Birincisi içerisinde Pseudomonas syringae pv. syringae, ikincisinde Pseudomonas syringae pv. morspurunorum 1rk 1, üçüncüsünde ise Pseudomonas syringae pv. morspurunorum 1rk 2, Pseudomonas syringae pv. avii ve Pseudomonas syringae pv. persicae'nin yer aldığını bildirmişlerdir. Aynı zamanda bu 5 patojen Prunus spp. (Sert çekirdekli meyve ağaçları)'da hastalığa neden olmaktadır (Kaluzna ve ark 2012).

Pseudomonas syringae pv. syringae ve Pseudomonas syringae pv. morsprunorum kirazlarda bakteriyel kansere neden olan önemli patojenlerdir. Hastalık etmeni patojenlerin ağacın kök hariç bütün organlarına ve yapılarına saldırması bu etmenlerin önemini daha da arttırmaktadır. Hastalığın tipik belirtisi çeşide, ağacın yaşına, bitki dokusuna, patojen izolata ve çevresel koşullara göre değişebilir (Gasic ve ark. 2012). Hastalık belirtileri içerisinde çiçek demeti yanıklığı, sürgünlerde geriye doğru ölüm, yaprak ve meyve lekeleri, odun dokularında açık yaralarla (kanser) birlikte zamklanma ve genel olarak meyve miktarında azalmalar şeklinde ortaya çıkmaktadır (Kennelly ve ark. 2007). Ancak en zararlı hali gövde ve dallarda görülmektedir. Kabuk, dal ve ince sürgünlerde yer alan kanserli dokulardan yaz ve ilkbaharın sonlarında bakteriyel akıntılar görülür. Kanserli dalların terminal yaprakları yaz veya sonbaharın başlarında dalın ucuna doğru yaprakların pörsümesi, sararması şeklinde gözlenir. Sonuçta yapraklar solar ve ölürler. Yaprak ve meyve infeksiyonları serin ve yağışlı havalarda önemli ekonomik kayıplara neden olur. Yaprak lekeleri koyu kahverengi, daireselden düzensiz şekillere kadar değişen lekeler şeklinde ve bazı zamanlarda sarı hale ile çevrilidir. Lekeler büyüyerek birleşir ve daha büyük ölü alanlar meydana getirir, lekelerin merkezleri dökülerek saçma ile delinmiş bir görüntü alır (Ogawa ve ark. 1995). Yeşil kiraz meyvelerindeki belirtileri ise su emmiş leke veya nemli bir alanla çevrilmiş kahverengi lekelerdir. İnfektelenmiş meyvelerde çökükderin çukurlar, siyah et benzeri lekeler ve meyvenin yaşına bağlı olarak merkezi sarı-kırmızı renginde lezyonlar meydana gelir. Meyve sapları kahverengi ve su emmiş leke şeklinde görülür. İnfekteli yaprak ve çiçek demetleri baharda açmaz ve ölü tomurcuk olarak adlandırılan belirtiler ortaya çıkar. Bu ölü sürgünlerde küçük kanserler görülür. Diğer infekteli demetler baharda açar fakat yaz başlarında ölür, yapraklar solar ve meyveler kurur (Ogawa ve ark. 1995). Dallarda derin yaralar şeklinde görülen kanser formu genelde ağacın zayıflamasına neden olan don olayları, yaralanma ve stres gibi faktörlerden sonra daha şiddetli gözlenir. Kanser oluşumunu don olayını teşvik eden gövdenin su içeriği, su emmiş lekeler ve büyük gövde çapları gibi faktörler teşvik etmektedir. Kanserli bölgeler konukçu-patojen ilişkisine göre küçük veya büyük olabilmekte ve ağacın ölümüne neden olabilmektedir. Kanserler, bakterinin kışı dormant olarak geçirdiği yerler olan çiçek demetlerinden ve tomurcuklardan odun dokusuna geçmesiyle başlamaktadır (Kennelly ve ark. 2007).Çiçek demeti infeksiyonu sonucunda ise demetin tamamı kurur. Etmen canlılığını bir üretim döneminden diğerine kanserli dokularda geçirir, sağlıklı sürgün ve iletim demetleri ile yayılır. Bakteri doku içerisinde baharda yağmurlarla beraber çoğalır ve genç yaprak ile çiçek demetlerine yağmur yardımıyla yayılır. Etmen simptom oluşturmadan epifitik olarak yaprak ve çiçeklerde de bulunabilir. Bakteriyel etmen yaprakların döküldüğü taze yaralardan gövdeye giriş yapar. Bakteriyel kanserin belirtileri ilkbaharda serin, nemli bir periyot veya yaprak ve çiçeklerden rüzgar nedeniyle oluşan yaraların olması durumunda ortaya çıkmaktadır. Yapraklarda serbest su filminin ve yüksek nemin en az 24 saat devam etmesi sonucunda yaprak infeksiyonları gerçekleşir (Jones ve Sutton 1996).

Pseudomonas syringae pv. syringae ülkemizde; Antalya, Mersin ve Adana'da Turunçgillerde (Mirik ve ark. 2005), Erzurum ve ilçelerinde kayıs1 ağaçlarında (Görmez 2011), Pseudomonas syringae pv. morsprunorum ise kirazda Marmara ve Ege Bölgesi, bademde ise Ege Bölgesinde görülebilmektedir (Anonim 2008).

Pseudomonas syringae pathovarlarının tanılama çalışmalarında, LOPAT, GATTa testleri gibi klasik yöntemlerin yanı sıra; patojenisite ve patolojik temelli fitotoksinlerinin dikkate alındığ in vitro' da syringomycin üretimi, buz çekirdeği oluşturma aktivitesinin saptanması kullanılmaktadır. Ayrıca, moleküler yöntemlerle de yapılan çalışmalar tanıları desteklemektedir (Ertimurtaş ve ark. 2014). 
Pseudomonas syringae pv. syringae'nin moleküler tanılanmasında kullanılan syrB geninin primerlerinin dizilimi, (B1 5'-CTTTCCGTGGTCTTGATGAGG-3' ve primer B2 5'- TCGATTTTGCCGTGATGAGTC-3') kullanılarak yapılır. Jele verildikten sonraki görüntüde primer uzunluğu 752-bp'ye ulaşmış ise etmen Pseudomonas syringae pv. syringae olarak tanilanır (Abbasi ve ark. 2014). Pseudomonas syringae pv. morsprunorum'un moleküler tanılanmasında kullanılan $c f l$ genine göre dizayn edilmiş primerler (GGCGCTCCCTCGCACTT ve GGTATTGGCGGGGGTGC) kullanılarak moleküler tanılanması yapılabileceği bildirilmiştir. Söz konusu primerlerin PCR ürünleri agaroz jelde 650 bp büyüklüğünde band oluşturmaktadır (Abelleria ve ark. 2014). Bu primer setleri izolatların pathovar düzeyinde moleküler tanısında son derece başarılı olarak kullanılmaktadır.

Bu çalışma kapsamında Tekirdağ ilinde kiraz üretimin yapıldığı Merkez, Naip, Kumbağ, Karahisarlı, Çanakçı, Barbaros yörelerinde 25 adet kiraz üretim alanı ziyaret edilmiş ve 129 adet ağaçtan örnek toplanmıştır. Yapılan izolasyonlar sonucu elde edilen 387 adet bakteri izolatının patojenitesi, LOPAT (L: Levan oluşumu, O: Oksidaz reaksiyonu, P: Pektolitik aktivite, A: Arginin dehidrolaz, T: Tütünde aşırı duyarlılık reaksiyonu), GATTa (G: Jelatin hidrolizi, A: Esculin hidrolizi, T: Tyrosine kullanma, Ta:Tartarik asidi kullanma) testleri, karbon kaynaklarından asit oluşumu gibi klasik testlerle tanısı yapılarak bakteri izolatlarının Pseudomonas syringae olduğu tanılanmıştır. İzolatların pathovar düzeyinde tanısında Pseudomonas syringae pv. syringae ve Pseudomonas syringae pv. morsprunorum'a spesifik olan yukarıda belirtilen iki primer seti kullanılarak PCR testleriyle moleküler düzeyde araştırmalar yapılmıştır. Ayrıca Tekirdağ ilinde kiraz dal kanseri hastalığının yaygınlığı, gezilen bahçelerdeki bulaşık ağaç sayısı oranı ve bulaşık ağaçtaki hastalık şiddeti tespit edilmiştir.

\section{MATERYAL}

\section{MATERYAL ve METOD}

Karakteristik hastalık belirtisi gösteren kiraz bitki örneklerinden izole edilen bakterilerin tanılanması çalışmalarında karşılaştırma kültürleri olarak Çukurova Üniveristesi Ziraat Fakültesi Bitki Koruma Bölümü Öğretim üyesi Prof. Dr. Yeşim AYSAN'dan temin edilen tanısı yapılmış Pseudomonas syringae pv. syringae izolatı, Tekirdağ Merkez ve çevresinden izole edilen Pseudomonas syringae pv. syringae izolatları, Yalova Bahçe Kültürleri Atatürk Araştırma Enstitüsü'nde çalışan Yük. Zir. Müh. Nesrin TUNALI'dan tanısı yapılmış Erwinia amylovora 57 izolatı, besi yerleri, çeşitli kimyasallar, laboratuar malzemeleri, inkübatör, etüv, otoklav, pH metre, spektrofotometre ve PCR aleti bu çalışmanın materyalini oluşturmuştur.

\section{Hastalığın Yaygınlığının Tespiti}

\section{METOD}

Arazi çalıșması için gidilen bahçelerdeki ağaçlar Lazarow (1961) metoduna göre incelenmiștir. Bu metoda göre 20 meyve ağacı olan bahçenin \%100'ü, 21-70 meyve ağacı olan bahçede 21-30 ağaç, 151-500 meyve ağacı olan bahçede 41-80 ağaç, 501-1000 meyve ağac1 olan bahçede ağaçların \%15' i, 1000' den fazla meyve ağacı olan bahçede ağaçların \%5' i (en az 150 ağaç) kontrol edilerek hasta bitki örnekleri Tekirdağ'ın Naip, Merkez, Mermer, Kumbă̆, Karahisarlı, Çanakçı, Barboros ve Kumbağ ilçelerinden toplanmıştır. Gezilen bölgedeki bahçe sayısına, hastalıklı bahçe sayısı oranlanarak hastalığın yöredeki yaygınlığı hesaplanmıştır. Ayrıca her kiraz bahçesi, çapraz olarak gezilmiş, hastalıklı ve sağlıklı ağaçların sayıları belirlenerek basit ortalama metoduna göre bahçelerdeki hastalık yüzdesi hesaplanarak hastalığın bahçedeki bulunma oranı tespit edilmiştir. Ayrıca infekteli ağaçlardaki hastalık şiddeti ise ortalama 10 ağaçta hastalıklı kısmın ağacın \% kaçını kapladığı hesaplanarak belirlenmiştir.

\section{Bakteriyel Kanser Etmeninin İzolasyonu}

Bakteriyel kanser belirtisi gösteren örneklerin hastalıklı ve sağlıklı doku kısımlarını içeren $0.5 \mathrm{~cm}$ 'lik bitki parçaları \% 70'lik alkol veya \%1'lik $\mathrm{NaOCl}$ ile yüzeyden dezenfekte edilmiştir. Parçalar steril havanda $\% 0.85 \mathrm{NaCl}$ içeren saline buffer da homojenize edilmiştir. Elde edilen ekstraktan bir öze dolusu süspansiyon alınarak King B

besi yeri içeren petrilere çizgi ekimiyle çizilmiştir. $25^{\circ} \mathrm{C}$ 'de 48 saatlik inkübasyondan sonra gelişen krem renkli koloniler saflaştırılmış ve gelecekteki çalışmalarda kullanılmak üzere eğik olarak hazırlanmış YDC ortamında $+4^{\mathrm{O}} \mathrm{C}$ 'de buzdolabında saklanmıştır (Lelliott ve Stead, 1987).

\section{Patojenite Testi}

Hastalıklı kiraz dokularından izole edilen bakteri izolatlarının patojenitesi Lelliott ve Stead (1987)'nin bildirdiğine göre 3 farklı yöntem kullanılarak yapılmıştır. Patojenite testi çalışmalarında $10^{8}$ hücre/ml inokulum yoğunluğu kullanılmıştır. Patojenite testlerinde pozitif kontrol olarak Pseudomonas syringae pv. syringae referans kültürü, negatif kontrol olarak ise steril su kullanılmıştır. Çalışmada çiçek demetlerine püskürtme, sürgünlerin uç kısımlarına injeksiyon ve meyve inokulasyonu olmak üzere üç farklı inokulasyon yöntemi kullanılmıştır.

\section{Re-İzolasyon}

İnokulasyon yapılan kiraz sürgün, açılmamış çiçek demetleri ve meyvelerinde meydana gelen kahverengilikler ve kurumalar incelemeye alınmıştır. Örnekler küçük parçalara ayrılmış ve \%70 etil alkol ile yüzeyden dezenfekte edilmiştir. Örnekler porselen havan içerisine konulmuş ve $2 \mathrm{ml}$ steril saline buffer eklenerek süspansiyonlar hazırlanmıştır. Havanlar 15-20 dakika bekletilerek bakterinin saline buffer süspansiyonuna geçmesi 
sağlanmıştır. Bekleme sonunda içerisinde King B besiyeri bulunan petrilere üç çizgi yöntemine göre çizimler yapılmıştır (Janse 2006). İzolasyon petrileri $25^{\circ} \mathrm{C}$ 'de 48 saat inkübatörde bekletilmiştir. King B besi yerinde floresan tipte, küçük, yuvarlak ve kabarık olmayan tipte krem renginde gelişen koloniler saflaştırılmıştır. Simptom veren bitkilerden re-izolasyonlar yapılarak elde edilen re-izolatlar cam tüplerde eğik olarak hazırlanmış yeast dekstroz kalsiyum karbonat agar (YDCA) besi yerine çizimleri yapılarak tanı çalışmaları yapılmak üzere buzdolabında saklanmıştır.

\section{Bakteri İzolatlarının Morfolojik, Fizyolojik ve Biyokimyasal Testlerle Tanısı}

129 hasta bitkiden izole edilen 387 izolat içinden seçilen 41 adet re-izolat ile tanı çalışmaları yapılmıştır. Geleneksel yöntemlerle tanı Lelliott ve Stead (1987) ile Schaad ve ark. (2001)'e göre yapılmıştır. KOH ile gram reaksiyonu ve LOPAT (L: levan oluşumu, O: oksidaz testi, P: patateste pektolitik aktivite, A: arginin dehidrolaz aktivitesi, T: tütünde aşırı duyarlılık reaksiyonu), GATTa (G: Jelatin hidrolizi, A: Esculin hidrolizi, T: Tyrosine kullanma, Ta:Tartarik asidi kullanma) testlerinin sonucuna göre izolatların tanıları yapılmıştır. Çalışmada Pseudomonas syringae pv. syringae'nin referans kültürü ile her bir test için pozitif ve negatif sonuç veren referans bakteri kültürleri kullanılmıştır.

\section{Bakteri İzolatlarının PCR Testi İle Tanısı}

Tekirdağ ilinden elde edilen 41 adet izolatın PCR ile tanısı yapılmıştır. İzolatlar nutrient broth sıvı besi yerinde geliştirilerek De Boer ve Ward (1995)'e göre saflaştırılmış genomik DNA'lar PCR çalışmalarında kullanılmıştır.

PCR çalışmasında syrB gen Primer B1 (5'-CTTTCCGTGGTCTTGATGAGG-3') ve syrB gen Primer B2 (5'TCGATTTTGCCGTGATGAGTC-3') (Bereswill 1992) ile $c f l$ gen Primer CFLF (5'-GGCGCTCCCTCGCACTT3') ve $c f l$ gen Primer CFLR (5'-GGTATTGGCGGGGGTGC-3') Abbasi 2013) primer setleri kullanılmıştır. Çalışma, reaksiyon tüpü adı verilen $0.5 \mathrm{ml}$ 'lik ince duvarlı eppendorf tüplerde toplam hacmi $25 \mu 1$ olan reaksiyon karışımının (12.5 $\mu$ 1 PCR Master Mix (Promega, M7502), $2.0 \mu 120$ pmole primer1 ve primer2, $6.5 \mu 1 \mathrm{H} 2 \mathrm{O}, 2.0 \mu 1 \mathrm{~g}-$ DNA) kullanılmasıyla gerçekleştirilmiştir. B1 ve B2 primerlerinin PCR işlemi için kullanılan program; İlk denatürasyon $94^{\circ} \mathrm{C}$ 'de 4 dak., 35 döngü $94^{\circ} \mathrm{C}$ 'de 1 dak., $60^{\circ} \mathrm{C}$ 'de 1.5 dak., $72^{\circ} \mathrm{C}$ 'de 1.5 dak., Final extention $72^{\circ} \mathrm{C}$ 'de 10 dak. olarak PCR cihazına programlanmıştır. CFLF ve CFLR primerlerinin PCR işlemi için kullanılan program ise İlk denatürasyon $93^{\circ} \mathrm{C}$ 'de 4 dak., 37 döngü $93^{\circ} \mathrm{C}$ 'de 1 dak., $52^{\circ} \mathrm{C}$ 'de 2 dak., $72^{\circ} \mathrm{C}$ 'de 1.5 dak., Final extention $72^{\circ} \mathrm{C}$ 'de 10 dak. olarak PCR cihazına programlanmıştır. Elde edilen bakteri DNA'sının ve PCR ürünlerinin Agarose jel elektroforezine yönelik çalışmalar Sambrook ve ark. (1989)'a göre yapılmıştır. Bunun için 0.9 g agarose $90 \mathrm{ml} 1$

$\mathrm{X}$ TAE tamponuna konularak mikrodalga firında eriyinceye kadar kaynatılmıştır. Yaklaşık $50{ }^{\circ} \mathrm{C}^{\prime}$ ye kadar soğutulan solüsyon, taraklar yerleştirilen jel tepsisine dökülmüştür. Agaroz jelin donmasından sonra jel tankı içerisine jeli örtünceye kadar 1XTBEbuffer konmuştur. Daha sonra örnek koymak için kullanılan tarak dikkatlice çekilerek çıkarılmıştır. Bu şekilde hazırlanan agaroz jel çukurlarına $3 \mu$ l loading buffer ve $12 \mu$ l PCR ürünü karışımı bir mikropipet yardımı ile dikkatlice verilmiştir. Moleküler ağırlık işaretleyici (Marker) olarak 100 bp DNA işaretleyici (Marker, Fermentas SM 0623) kullanılmıştır. Elektroforez tankında agroz jeldeki örnek hücrelerin bulunduğu yer güç kaynağının negatif (-) kutbuna denk gelecek şekilde yerleştirilmiş ve PCR ürünleri $100 \mathrm{~V}$ elektrik akımında yaklaşık 1 saat süre ile yürütülmüştür. Bantların görülmesi için ethidium bromür ile $(10 \mathrm{mg} / \mathrm{ml}) 10$ dak. boyama yapılmış ve bunu takiben 15 dak. saf su ile jel yıkanarak transliminatörde $(302 \mathrm{~nm})$ bantlar incelenmiş ve fotoğraflanmıştır.

\section{BULGULAR VE TARTIŞMA}

Hastalıklı Bitki Materyalinin Elde Edilmesi:Tekirdağ ilinde7 farklı yörede Merkez, Naip, Mermer, Kumbă̆, Karahisarlı, Çanakçı, Barboros kiraz üretim alanlarına 2012 ve 2013 yılının Mart-Haziran aylarında periyodik olarak ziyaretler yapılmış ve ziyaret edilen kiraz bahçelerinde bakteriyel kanserin neden olduğu karakteristik hastalık belirtileri olan çiçek demeti yanıklığı, sürgünlerde geriye doğru ölüm, yaprak ve meyve lekeleri ile odun dokularında kanserle birlikte zamklanma belirtileri gözlenmiştir. Arazi çalışmalarında ziyaret edilen bahçelerde hastalığın bulunma oranı \%100 olarak belirlenmiştir. Tekirdağ ili mevkilerine göre ziyaret edilen bahçelerde hastalığın bulunma oranları ise Naip'te \%35.6, Mermer'de \%33.3, Merkez'de \%17.4, Kumbağ'da $\% 38.5$, Karahisarlı'da \%25.0, Çanakçı'da \%20.0, Barboros' ta \%57.1 olarak belirlenirken, hastalık şiddetinin ise \%28.5-50.7 arasında değişen oranlarda belirlenmiştir.

Hastalık etmeninin izolasyonu:Tekirdağ çevresinde bakteriyel kanser belirtisi gösteren 129 adet bitki örneğinin hastalıklı ve sağlıklı doku kısımlarını içeren parçalardan King B besi yerine yapılan izolasyonlarda 2-3 gün içinde krem-beyaz renkte ve floresan tipte kolonilerden 387 adet bakteri izolatı elde edilmiş ve tanı testleri yapılmıştır.

Patojenite testinde kullanılan bakteri populasyonunun hesaplanması: King B besi yerinde geliştirilen 48 saatlik izolatlar spektrofotometrede $600 \mathrm{~nm} 0.1$ absorbans değerine ayarlanarak süspansiyonlar hazırlanmış ve yapılan seyreltme serilerinden besiyerinde gelişen koloniler sayılarak ml' deki bakteri populasyonu 7 x $10^{8}$ hücre/ml yoğunluğunda olduğu hesaplanmıştır (Klement ve ark. 1990). 
Patojenite testi:Hastalıklı kiraz dokularından izole edilen ve tanı çalışmasında kullanılan 41 bakteri izolatı ve referans kültür King B besi yerinde geliştirilen 24 saatlik bakteri izolatlarının 7 x $10^{8}$ hücre/ml yoğunluğundaki süspansiyonları hazırlanmıştır. Namık Kemal Üniversitesi Ziraat Fakültesi Bahçe bitkileri Demonstrasyon Kiraz bahçesinden toplanan çiçek, sürgün ve meyvelere inokulasyon yapılmış ve $25^{\circ} \mathrm{C}$ ve $\% 70$ nem içeren sera bölmesinde muhafaza edilmiştir. Pozitif kontrolle bulaşık bitkilerde diştan gözle görülür simptomlar oluşunca yaklaşık çiçek ve sürgünler 8-10 gün sonra meyve denemeleri ise 5-7 gün sonra değerlendirme yapılmıştır (Janse 1981). Tipik hastalık simptomu gösteren bitkilerden yapılan re-izolasyonlar sonucu seçilen 41 re-izolat tekrar izole edilmiş ve tanı testlerinde kullanılmıştır.

Bakteri İzolatlarının Morfolojik, Fizyolojik ve Biyokimyasal Testlerle Tanısı:Hastalık belirtisi gösteren kiraz bahçelerinden izole edilen 41 adet bölge izolatı ve bir referans izolat olmak üzere 42 adet re-izolatla yapılan tanı çalışmaları sonucunda; izolatlar King B besi yerinde krem renkli flouresan koloni, gram negatif, levan tipte koloni oluşumu ve tütünde aşırı duyarlılık pozitif olarak belirlenmiştir. Oksidaz, pektolitik aktivite ve arginin dehidrolaz ise negatif olarak belirlenmiştir. İzolatların tür ayırımında kullanılan GATTa testi sonucunda iki gruba ayrılmıştır. Birinci grup içerisinde yer alan 23 izolatın GATTa sonuçları -, -, +, + olarak belirlenmiş ve bunların Pseudomonas syringae pv.morsprunorum olduğu belirlenmiştir. Geriye kalan 23 izolatın ise GATTa sonuçları +, +, -, - olarak saptanmış, izolatların Pseudomonas syringae pv.syringae olarak tanıları yapılmıştır. İzolatlara yapılan tanı testlerinin sonuçları Çizelge 1 'de özetlenmiştir.

Çizelge 1. Bakteri izolatlarının test sonuçları

\begin{tabular}{|c|c|c|c|c|c|c|c|c|c|c|c|c|c|c|}
\hline \multirow{2}{*}{ İzolat Adı } & \multirow{2}{*}{$\begin{array}{c}\text { Gram } \\
\text { Reaksiyon }\end{array}$} & \multirow{2}{*}{$\mathbf{F}$} & \multirow{2}{*}{$\mathbf{L}$} & \multirow{2}{*}{$\mathbf{O}$} & \multirow{2}{*}{$\mathbf{P}$} & \multirow{2}{*}{$\mathbf{A}$} & \multirow{2}{*}{$\mathbf{T}$} & \multirow{2}{*}{$\mathbf{G}$} & \multirow{2}{*}{$\mathbf{A}$} & \multirow{2}{*}{$\mathbf{T}$} & \multirow{2}{*}{ Ta } & \multicolumn{2}{|c|}{ PCR } & \multirow{2}{*}{$\begin{array}{c}\text { Tanı } \\
\text { Sonucu }\end{array}$} \\
\hline & & & & & & & & & & & & $C f l$ & syrB & \\
\hline Naip 1/1 & - & + & + & - & - & - & + & + & + & - & - & - & + & Pss \\
\hline Naip 2/1 & - & + & + & - & - & - & + & + & + & - & - & - & + & Pss \\
\hline Naip 3/1 & - & + & + & - & - & - & + & + & + & - & - & - & + & Pss \\
\hline Naip 4/1 & - & + & + & - & - & - & + & + & + & - & - & - & + & Pss \\
\hline Naip 5/1 & - & + & + & - & - & - & + & + & + & - & - & - & + & Pss \\
\hline Naip 6/1 & - & + & + & - & - & - & + & + & + & - & - & - & + & Pss \\
\hline Naip 7/1 & - & + & + & - & - & - & + & + & + & - & - & - & + & Pss \\
\hline Naip 8/1 & - & + & + & - & - & - & + & - & - & + & + & + & - & Psm \\
\hline Naip 9/1 & - & + & + & - & - & - & + & - & - & + & + & + & - & Psm \\
\hline Naip 10/1 & - & + & + & - & - & - & + & - & - & + & + & + & - & Psm \\
\hline Naip 11/1 & - & + & + & - & - & - & + & - & - & + & + & + & - & Psm \\
\hline Naip 12/1 & - & + & + & - & - & - & + & - & - & + & + & + & - & Psm \\
\hline Naip 13/1 & - & + & + & - & - & - & + & - & - & + & + & + & - & Psm \\
\hline Naip 14/1 & - & + & + & - & - & - & + & - & - & + & + & + & - & Psm \\
\hline Naip 15/1 & - & + & + & - & - & - & + & - & - & + & + & + & - & Psm \\
\hline Naip 16/1 & - & + & + & - & - & - & + & - & - & + & + & + & - & Psm \\
\hline Mermer 1/1 & - & + & + & - & - & - & + & + & + & - & - & - & + & Pss \\
\hline Mermer 2/1 & - & + & + & - & - & - & + & + & + & - & - & - & + & Pss \\
\hline Mermer 3/1 & - & + & + & - & - & - & + & + & + & - & - & - & + & Pss \\
\hline Mermer 4/1 & - & + & - & - & - & - & + & + & + & - & - & - & + & Pss \\
\hline Merkez 1/1 & - & + & + & - & - & - & + & - & - & + & + & + & - & Psm \\
\hline Merkez 2/1 & - & + & + & - & - & - & + & - & - & + & + & + & - & Psm \\
\hline Merkez 3/1 & - & + & + & - & - & - & + & - & - & + & + & + & - & Psm \\
\hline Merkez 4/1 & - & + & + & - & - & - & + & - & - & + & + & + & - & Psm \\
\hline Kumbağ 1/1 & - & + & + & - & - & - & + & - & - & + & + & + & - & Psm \\
\hline Kumbağ 2/1 & - & + & + & - & - & - & + & - & - & + & + & + & - & Psm \\
\hline Kumbağ 3/1 & - & + & + & - & - & - & + & - & - & + & + & + & - & Psm \\
\hline Kumbağ 4/1 & - & + & + & - & - & - & + & - & - & + & + & + & - & Psm \\
\hline Kumbağ 5/1 & - & + & + & - & - & - & + & - & - & + & + & + & - & Psm \\
\hline Karahisarlı 1/1 & - & + & + & - & - & - & + & - & - & + & + & + & - & Psm \\
\hline Karahisarlı 2/1 & - & + & + & - & - & - & + & - & - & + & + & + & - & Psm \\
\hline Karahisarlı 3/1 & - & + & + & - & - & - & + & - & - & + & + & + & - & Psm \\
\hline Çanakçı 1/1 & - & + & + & - & - & - & + & - & - & + & + & + & - & Psm \\
\hline Barbaros 1/1 & - & + & + & - & - & - & + & + & + & - & - & - & + & Pss \\
\hline Barbaros 2/1 & - & + & + & - & - & - & + & + & + & - & - & - & + & Pss \\
\hline
\end{tabular}




\begin{tabular}{|l|c|c|c|c|c|c|c|c|c|c|c|c|c|c|}
\hline Barbaros 3/1 & - & + & + & - & - & - & + & + & + & - & - & - & + & Pss \\
\hline Barbaros 4/1 & - & + & + & - & - & - & + & + & + & - & - & - & + & Pss \\
\hline Barbaros 5/1 & - & + & + & - & - & - & + & + & + & - & - & - & + & Pss \\
\hline Barbaros 6/1 & - & + & + & - & - & - & + & + & + & - & - & - & + & Pss \\
\hline Barbaros 7/1 & - & + & + & - & - & - & + & + & + & - & - & - & + & Pss \\
\hline Barbaros 8/1 & - & + & + & - & - & - & + & - & - & + & + & + & - & Psm \\
\hline
\end{tabular}
F: King B'de floresan tip koloni gelişimi, L: Levan oluşumu, O: Oksidaz reaksiyonu, P: Pektolitik aktivite, A:
Tyrginin dehidrolaz, T: Tütünde aşirı duyarlilik reaksiyonu, G: Jelatin hidrolizi, A: Esculin hidrolizi, T:
syringae pv. morsprunorum

Elde edilen re-izolatların tanılarının yapılmasında mutlaka GATTa testinin kullanılması gerektiği bu çalışma ile de ortaya konmuştur. Re-izolatlarla yapılan GATTa testi sonucunda iki gruba ayrılmıştır. Birinci grup içerisinde yer alan 23 izolatın GATTa sonuçları -, -, +, + olarak belirlenmiş ve bunların Pseudomonas syringae pv. morsprunorum olduğu belirlenmiştir. Geriye kalan 23 izolatın ise GATTa sonuçları +, +, -, - olarak saptanmış izolatların Pseudomonas syringae pv. syringae olarak tanıları yapılmıştır.

Bakteri İzolatlarının PCR Testiyle Tanısı: B1-B2 primerleri kullanılarak yapılan PCR testlerinde 18 re-izolatın (Naip1/1, Naip 2/1, Naip3/1, Naip 4/1, Naip5/1, Naip 6/1, Naip7/1, Mermer 1/1, Mermer 2/1, Mermer 3/1, Mermer 4/1, Barboros 1/1, Barboros 2/1, Barboros 3/1, Barboros 4/1, Barboros 5/1, Barboros 6/1, Barboros 7/1) \%1.5 agaroz jelde 752 bp büyüklüğünde bantlar oluşturmuştur. Moleküler ağırlık işaretleyicisi olarak kullanılan 100 bp'lik marker PCR ürününün 752 bp büyüklüğünde olduğu Şekil 4. 18'de görülmektedir. B1-B2 pimerleri kullanılarak yapılan PCR çalışması sonucunda 18 adet izolatın Pseudomonas syringae pv.syringae olduğu belirlenmiştir. CFLFCFLR primerleri ile yapılan PCR çalışmasında ise re-izolatların 23 adedi (Naip 8/1, Naip 9/1, Naip 10/1, Naip 11/1, Naip 12/1, Naip 13/1, Naip 14/1, Naip 15/1, Naip 16/1, Merkez 1/1, Merkez 2/1, Merkez 3/1, Merkez 4/1, Kumbağ 1/1, Kumbağ 2/1, Kumbağ 3/1, Kumbağ 4/1, Kumbă̆ 5/1, Karahisarli 1/1, Karahisarli 2/1, Karahisarli 3/1, Çanakçı 1/1, Barboros 8/1) \%1.5 agaroz jelde Şekil 4.19'da görüldüğü gibi 650 bp baz uzunluğu oluşturarak Pseudomonas syringae pv. syringae olarak tanımlanmıştır.

Çizelge 1'de de görüldüğ̈̈ üzere izolatların tanılama çalışmalarında kullanılan klasik yöntemlerden LOPAT karakterizasyonuna göre izolatların tamamı +,-,-,-,+ özellikler göstererek Pseudomonas syringae olduğu ortaya konulmuştur. Elde edilen re-izolatların tanılarının yapılmasında mutlaka GATTa testinin kullanılması gerektiği bu çalışma ile de ortaya konmuştur. Re-izolatların yapılan GATTa testi sonucunda iki gruba ayrılmıştır. Birinci grup içerisinde yer alan 23 izolatın GATTa sonuçları -, -, +, + olarak belirlenmiş ve bunların Pseudomonas syringae pv. morsprunorum olduğu belirlenmiştir. Geriye kalan 18 izolatın ise GATTa sonuçları +, +, -, - olarak saptanmış izolatların Pseudomonas syringae pv. syringae olarak tanıları yapılmıştır.

Ivanovic ve ark (2009) izolatların GATTa testine göre iki farklı gruba ayrıldığını belirlemiştir. GATTa birinci grupta yer alan izolatlar jelatin ve esculini hidrolize ederken thyrosinaz ve tartatatı kullanmamalarından dolayı Pseudomonas syringae pv. syringae olarak tanılamışlardır. İkinci grup içinde bulunan izolatlar jelatin ve esculin hidrolize etmezken, thyrosinaz ve tartarattan kullanmalarından dolayı Pseudomonas syringae pv. morsprunorum olarak tanılanmıştır. Kaluzna ve ark. (2010) farklı sert çekirdekli meyvelerden izole ettikleri 30 adet Pseudomonas 'nn 23 adedi LOPAT testlerine göre Pseudomonas syringae olarak tanılanmıştır. Tam olarak tür ayırımını yapmak için GATTa kullanmaları sonucunda 10 tanesi Pseudomonas syringae pv. morsprunorum 1rk 1, 6 tanesi Pseudomonas syringae pv. morsprunorum 1rk 2 ve 6 tanesi de Pseudomonas syringae pv. syringae olarak tanılamışlardır. Gavriloviç ve ark. (2012) ise kiraz üretim alanlarından elde ettiği Pseudomonas izolatlarının tanısını patojenite testi ve GATTa testine jelatin ve esculin pozitif, tyrisonas ve tartarat ise negatif olarak Pseudomonas syringae pv. syringae olarak, jelatin ve esculin negatif, tyrosine ve tartarat ise pozitif olan izolatları ise Pseudomonas syringae pv. morsprunorum olarak tanılanmıştır. Gasic ve ark. (2012) gram reaksiyonu, KB'de floresan ve LOPAT testleri Pseudomoas türlerini birbirinden ve bazı diğer cinslerden ayırmada kullanılan testler olarak kullanılabileceğini belirtmiştir. GATTa testi Pseudomonas syringae pv. syringae ve Pseudomonas syringae pv. morsprunorum 1rk 1 ayırmada kullanılırken (Latorre ve Jones 1979) Pseudomonas syringae pv. morsprunorum 1rk 2'de ise uygun olmamıştır (Gilbert ve ark. 2009). Pseudomonas syringae pv. morsprunorum 1rk 2 jelatin ve esculini hidrolize etmiş, tyrosine üretmiş ama tartarik asidi kullanmamıştır. GATTa testi Pseudomonas syringae pv. morsprunorum 1rk 1 için uygun olduğu belirlenmiştir. Pseudomonas syringae pv. morsprunorum 1rk 1 jelatin ve esculini hidrolize etmezken tyrosine ve tartarik asidi kullanmaktadır (Bultreys ve Kaluzna 2010). Bu yüzden GATTa testinde Pseudomonas syringae pv. morsprunorum 1rk 1 ve irk 2'yi ayırmada sadece jelatin hidrolizi kullanılabilir. Vicente ve Roberts (2007) bazı Pseudomonas syringae pv. morsprunorum 1rk 2 izolatlarının GATTa test sonucu (++--) Pseudomonas syringae pv. syringae' ye benzer olduğunu bildirmiştir. Bunun yanında GATTa test Pseudomonas syringae pv. syringae ve Pseudomonas syringae pv. morsprunorum ayırmada kullanılacak bir yöntem olduğu ama Pseudomonas syringae pv. morsprunorum ırk 2 için buz çekirdeği aktivitesi, sukroz nutrient broth besiyerinde 
gelişim ve insitoldan asit üretimi gibi ekstra testlerin eklenmesi gerekmektedir. Pseudomonas syringae pathovarlarının simptomolojik ve genel karakteristik özellikleri nedeniyle sert çekirdeklilerde ayırımı kolaylıkla karıştırılabilmektedir. Sadece LOPAT testi Pseudomonas syringae pv. syringae ve Pseudomonas syringae pv. morsprunorum ayırmada yeterli olmadığ 1 gerek yaptığımız çalışmada gerekse diğer yapılan çalışmalarda da görüldüğü gibi uygun olmamaktadır. Bu nedenle yapılan bütün çalışmalar GATTa gibi ayırıcı testlerin yapılması daha doğru sonuçların alınmasında faydalı olacaktır. Ayrıca elde edilen re-izolatların tanısında moleküler yöntemlerle desteklenmesinin gerektiği birçok araştırmacı tarafaından önerilmektedir. İki farklı primer dizilimleri kullanılarak yapılan PCR çalışmaları sonucunda elde edilen re-izolatların iki farklı tür olduğu saptanmıştır. İzolatların 23 tanesi $c f l$ genine göre elde edilen primerlere reaksiyon verirken 18 adet izolat ise $s y r B$ genine göre dizayn edilen primerlerle reaksiyon vermiştir. Bu reaksiyonlar sonucunda elde edilen verilerle GATTa testinden elde edilen sonuçlar benzerlik göstermiştir. $c f l$ genine göre reaksiyon veren ve 650 bp baz uzunluğunda ürün veren izolatların Pseudomonas syringae pv. morsprunorum olarak tanılanırken, syrB genine reaksiyon veren ve $752 \mathrm{bp}$ baz uzunluğunda tekrarlanabilen bantlar oluşturan izolatlar ise Pseudomonas syringae pv. syringae olarak tanılanmıştır. Gasic ve ark. (2012) PCR metotlarında toksin üretimlerinin belirlenmesinde, Pseudomonas syringae pv. syringae için syrB ve syrD, Pseudomonas syringae pv. morsprunorum için $c f l$ genlere dayalı PCR testlerinin izolaların ayırımında yeterli olacağını bildirmiştir. Ertimurtaş ve ark. (2014) Pseudomonas syringae pathovarlarının moleküler yöntemlerle yapılan tanısinda Pseudomonas syringae pv. syringae 'nin syringomycin sentezinden sorumlu syrB geni ve Pseudomonas syringae pv. morsprunorum 'nin coronatine sentezinden sorumlu cfl genlerine göre belirlemiştir. Benzer olarak Abbasi ve ark. (2012) Pseudomonas syringae pv. syringae 'nin moleküler tanılanmasında syrB genine göre dizayn edilen primer kullanıldığında 752bp baz uzunluğunda PCR ürünleri elde edilirken, Albelleria ve ark. (2014) yaptıkları çalışmada Pseudomonas syringae pv. morsprunorum 'un moleküler tanılanmasında kullanılan $c f l$ geninin kullanıldığı PCR çalışmalarında ise 650 bp baz uzunluğunda PCR ürünlerinin elde edildiğini belirlemişlerdir. Elde ettiğimiz sonuçlar ile araştırıcıların sonuçları paralellik göstermektedir.

\section{TEŞEKKÜR}

Bu çalışma Namık Kemal Üniversitesi Bilimsel Araştırma Proje ofisi tarafından NKUBAP.00.24.YL.14.06 nolu proje olarak desteklenmiştir.

\section{LITERATÜR LİSTESI}

Abbasi, V., Rahminian, H., Ghanbari, M. A. T. 2012. Genetic variability of Iranian strains of Pseudomonas syringae causing bacreial canker disease on stone fruits. Eur J Plant Pathol, 135: 225-235.

Abbasi, V., Rahimian, H. and Tajick-Ghanbari, M. A. 2013. Genetic variability of Iranian strains of Pseudomonas syringae pv. syringae causing bacterial canker disease of stone fruits. European journal of plant pathology, 135: 225-235.

Abelleira, A., Ares, A., Augin, O., Picoaga, A., Lopez, M. M., Mansilla, P. 2014. Current situation and characterization of Pseudomonas syringae pv. actinidae on kiwifruit in Galicia (northwest Spain).Plant Pathology, 691-699.

Anonim 2008. Sert çekirdekli meyvelerde bakteriyel yanıklık hastalığı. Zirai Mücadele Teknik Talimatları, Ankara, Cilt 4, 66-68.

Burak, M. 2003. Meyvecilik-1, 147-151.

De Boer, S. H., Ward, L. J. 1995. PCR detection of Erwinia caratovora subsp. atroseptica associated with potato tissue. Phytopathology, 85:854-858.

Ertimurtaş, D., Özaktan, H. 2014. Sert çekirdekli meyvelerde bakteriyel kansere neden olan Pseudomonas syringae pathovarlarının tanısı. Türkiye V. Bitki Koruma Kongresi, Antalya.

Gavrilovic, V., Zivkovic, S., Dolovac, N., Trkulja, N., Dolovac, E. P., Popovic, T., Ivanovic, D., 2012. Pseudomonas syringae-pathogen of sweet cherry in Serbia. Pestic. Phytomed, 27(2): 141-149.

Gerçekçioğlu, R., Bilginer, Ş., Soylu, A. 2006. Genel meyvecilik (Meyve yetiştiriciliği esasları kitabı).

Görmez, A. 2011. Erzurum ilinde kayısı ağaçlarından izole edilen Pseudomonas türlerinin tanısı, karakterizasyonu ve çeşit reksiyonları. Doktora tezi, Atatürk Üniversitesi Fen Bilimleri Enstitüsü, Erzurum. 
Ivanovic, Z., Zivkovic, S., Starovic, M., Josic, D., Stankovic, S., Gavrilovic, V. 2009. Diversity among Pseudomonas syringae strains originating from fruit trees in Serbia. Arch. Biol. Sci., 61(4): 863-870.

Janse, J. D. 1981. The bacterial disease of ash (Fraxinus excelsior), caused by Pseudomonas syringae subsp. savastanoi pv. fraxini. II. Etiology and taxonomic considerations. European Journal of Forest Pathology, 11: 425-38.

Janse, J. D. 2006. Phytobacteriology. Principles and Practice. Wallingford, UK and Oxford Press, New York, 208209.

Jones, A. L., Sutton, T. B. 2006. Pseudomonas syringae pv. syringae and Pseudomonas syringae pv. morsprunorum. West Virginia University, 1-3.

Kaluzna, M., Ferrante, P., Sobiczewski, P., Scortichini, M. 2010. Characterization and genetic diversity of Pseudomonas syringae from stone fruits and hazelnut using repetiyive-PCR and MLST. Journal of Plant Pathology, 92(3): 781-787.

Kaluzna, M., Janse, J. D., Young, J. M. 2012. Detection and identification methods and new tests as used and developed in the framework of cost 873 for bacteria pathogenic to stone fruits and nuts. Journal of Plant Pathology, 94(1): 117-126.

Kennely, M. M., Cazorla, F. M., Vicente, A., Ramos, C., Sundin, G. W. 2007. Pseudomonas syringae disease on fruit trees. Plant Disease, 91(1).

Klement, Z., Rudolph, K., Sands, D. C. 1990. Methods in Phytobacteriology, Akademia Kiado, Budapest, $\mathrm{XIV}+568 \mathrm{p}$

Lelliot, R. A., Stead, D. E. 1987. Methods for the Diagnosis of Bacterial Diseases of Plants. Oxford, UK: Blackwell Scientific Publications.

Mirik, M., Baloğlu, S., Aysan, Y., Çetinkaya Yıldız, R., Küsek, M. and Şahin, F. 2005. First outbreak and occurrence of citrus blast disease, caused by Pseudomonas syringae pv. syringae on orange and mandarin trees in Turkey. Plant Pathology, 54 (2): 238.

Ogawa, J. M., Zehr, E. L., Bird, G. W., Ritchie, D. F., Uriu, K. and Uyemoto, J. K. 1995. Compendium of stone fruit diseases, 78-87.

Sambrook, J., Fritsch, E. F. and Maniatis, T. 1989. Molecular Cloning. A laboratory manual. $2^{\text {nd }}$ ed. N.Y., Cold Spring Harbor Laboratory Press, 1659 p.

Schaad, N. W., Jones, J. B. and Chun, W. 2001. Laboratory Guide for Identification of Plant Pathogenic Bacteria. The American Phytopathological Society, St. Paul, MN., USA.

TÜİK, 2013. www.tuik.gov.tr. Türkiye'de kiraz ağaç sayısı ve üretim miktarı. 23\07\2014. 